\title{
ARTIKELEN
}

\section{Een einde aan ondermijning}

\section{Over de opkomst en werking van een nieuwe veiligheidsstrategie}

\author{
Hans Boutellier, Ronald van Steden, Yarin Eski \& Mauro Boelens
}

\begin{abstract}
Ondermijning is een buzz-woord binnen de Nederlandse politiek en het veiligheidsbeleid. Op nationaal en lokaal niveau zijn er grote zorgen over vermenging van de bovenwereld en de onderwereld die de democratische rechtsorde aantast. Zodoende zou alles op alles gezet moeten worden om het sluipende gevaar van ondermijning aan te pakken. Echter, wat is ondermijning nu precies? En waarom slaat het begrip nu zo bijzonder hard aan? In deze bijdrage staan de auteurs stil bij deze en enkele andere belangrijke vragen over de opkomst en de inzet van het begrip ondermijning om zo meer conceptuele helderheid te bieden. Door een kritische reflectie op ondermijning als speech act, namelijk 'ondermijnisering' (cf. securitisering), en op basis van empirisch onderzoek, kan gesteld worden dat er twee discoursen zijn die de effectiviteit van het begrip bemoeilijken: één specifiek toegespitst op de drugsindustrie met alle illegale activiteiten daaromheen en één die in de breedte gaat over onwettelijk en onwenselijke ontwikkelingen die maatschappelijke continuïteit dwarsbomen. Concluderend stellen de auteurs dat het begrip ondermijning beleidsmatig mobiliserend werkt, maar operationeel een verlammend effect dreigt te hebben.
\end{abstract}

Ondermijning is een buzz-woord binnen de Nederlandse politiek en het veiligheidsbeleid. De politie waarschuwt voor een vergaande 'vermenging van de bovenwereld en de onderwereld' die 'ons allemaal raakt', ${ }^{1}$ het Openbaar Ministerie maakt zich ernstig zorgen over een soort criminaliteit 'die maatschappelijke structuren of het vertrouwen daarin schaadt'2 en de Vereniging van Nederlandse Gemeenten wijst erop dat de aanpak van ondermijning 'al langer geen exclusieve taak van de politie en het Openbaar Ministerie' meer is en pleit voor een 'georganiseerde overheid die alle instrumenten en middelen inzet die ze tot haar beschikking heeft'. ${ }^{3}$

Tien Regionale Informatie en Expertise Centra (RIEC's) en het Landelijk Informatie en Expertise Centrum (LIEC) richten zich op de bestrijding van ondermijnende criminaliteit, compleet met jaarverslagen en een eigen e-zine: 'Code Geel'. ${ }^{4}$ Inmiddels is er vanuit het ministerie van Justitie en Veiligheid een pro-

1 www.politie.nl/themas/ondermijning.html.

2 www.om.nl/onderwerpen/ondermijnende.

3 https://vng.nl/onderwerpenindex/veiligheid/ondermijning.

4 www.riec.nl. 
gramma 'anti-ondermijning' opgetuigd, waarmee het 'ruimhartig' $€ 100$ miljoen ter beschikking heeft gesteld om overheidspartijen, liefst in samenwerking met andere partijen, de criminele business in 'het hart' te raken. ${ }^{5}$ Ook hebben lokale overheden een 'meervoudige aanpak van ondermijnende criminaliteit' geïnitieerd. ${ }^{6}$ Tel daarbij het aantal congressen, symposia, workshops en nieuwsberichten over 'ondermijning' op en we kunnen gerust stellen dat het begrip ondermijning een game changer in de veiligheidswereld is gebleken.

Daarbij valt op dat ondermijning een veelomvattend begrip is dat voor allerlei ongewenste en verstorende gedragingen wordt ingezet, waardoor precisie en helderheid ontbreken - het heeft klaarblijkelijk een sterke verleidingskracht. Waar komt ondermijning vandaan, en waar gaat deze veiligheidsstrategie naartoe? Waarom is ondermijning zo in zwang geraakt onder bestuurders en beleidsmakers? Het doel van dit artikel is om meer conceptuele helderheid te bieden. Daartoe gaan we in op de opkomst en de inzet van het begrip ondermijning. Vervolgens constateren we dat er twee discoursen zijn die de effectiviteit van het begrip in de weg staan. Geleidelijk heeft het begrip zich toegespitst op de drugsindustrie; daar zijn in de Nederlandse context ook goede redenen voor. We concluderen dat het begrip ondermijning beleidsmatig mobiliserend werkt, maar operationeel een verlammend effect dreigt te hebben.

\section{1 'Ondermijnisering'}

Het concept ondermijning genereert in zijn 'mentale betekenis' veel publieke en politieke aandacht en organiseert de politieke agenda. In het programma van het Strategisch Beraad Ondermijning wordt de nadruk gelegd op drugscriminaliteit en de effecten daarvan, maar in andere beleidscircuits bestaat ook aandacht voor andere vormen. Er is inmiddels behoorlijk wat kritiek op deze onhelderheid. Diverse auteurs wijzen op de gevaren van een te brede benadering van de problematiek, waardoor de precisie in instrumentarium, maar ook in rechtsbescherming ontbreekt (Brouwer, 2018; Eysink Smeets, 2018; Hoogenboom, 2018). We spreken - met excuses voor het lelijke woord - van 'ondermijnisering' van de veiligheid: we kijken steeds meer door de bril van ondermijning naar risico's in de samenleving (Boutellier, 2018). Maar door wat voor bril kijken we dan en zijn de glazen wel sterk genoeg?

Ondermijnisering is afgeleid van het internationaal veel gebezigde 'securitisering' (Buzan e.a., 1998: 23): '.. an intersubjective process that is the most extreme or the highest level of politicisation in which the issue is presented as an existential threat to the referent object by a securitising actor through so-called "speech acts" and requiring emergency measures and justifying actions outside the normal bounds of political procedure'. Zo een 'speech act' zien we terug in het ondermijningsbeleid, bijvoorbeeld in een conferentietoespraak van minister van Justitie en Veiligheid Grapperhaus:

5 https://magazines.rijksoverheid.nl/jenv/jenvmagazine/2018/02/hoofdartikel.

6 www.dordrecht.nl/pls/idad/mozEgemDocument?F_DOCNR=5769736. 
'Ondermijnende criminaliteit, dat is misdaad die de burger bedreigt en de buurt besmet. Ondermijnende criminaliteit is misdaad die georganiseerd is en welbewust gewone mensen in hun degelijke bestaan omstrengelt. De onderwereld die de bovenwereld aantast. Die ondermijnende criminaliteit gaan we met nog meer kracht keihard aanpakken. Samen. Daarvoor heeft dit kabinet de extra middelen ter beschikking gesteld.' (Rijksoverheid, 2018)

In ferme, medisch-diagnostische taal worden de effecten en aanpak van ondermijnende criminaliteit beschreven. Deze is besmettelijk en slecht en moet met man en macht worden aangepakt, waarvoor middelen zijn vrijgemaakt. Ondermijnisering is daarmee ook 'a self-referential practice, because it is in this practice that the issue becomes an issue - not necessarily because a real existential threat exists, but because the issue is presented as such a threat' (Buzan et al., 1998: 24). Het geeft stof tot nadenken over de vraag of ondermijning wel bestaat. Evenals over de vraag waarom dit narratief, of deze taal, ineens in de politiek en beleidsaanpak aanslaat. Er is het reële risico dat politie en justitie in de aanpak van ondermijnende criminaliteit zelf het welzijn van de samenleving en de democratische rechtsstaat ondermijnen. In dat verband analyseren we ondermijning als een 'speech act'.

\section{Het begin van het spreken van ondermijning}

In de internationale wetenschappelijke literatuur is de term 'ondermijning' nauw verbonden met spionage en andere operaties van vijandige mogendheden. Powelson (2003) bespreekt bijvoorbeeld hoe de Verenigde Staten door steun aan guerrillabewegingen in Afghanistan en Tsjetsjenië het democratische proces in Rusland proberen 'te ondermijnen'. Of neem Theoharis (2003) die in een historische verhandeling over de Koude Oorlog uitlegt dat de Amerikanen niet alleen bang waren voor de Sovjet-Unie als gewapende tegenstander, maar ook voor de mogelijkheid dat er in eigen land spionnen konden worden gerekruteerd. Zij zouden de Russen van waardevolle informatie voorzien om de Amerikaanse staat 'te ondermijnen', terwijl de Amerikanen er op hun beurt alles aan deden om potentiële spionnen 'te ondermijnen'. De heksenjacht op (vermoedelijke) communisten onder president McCarthy was er het gevolg van.

Dit denken in termen van een (mogelijke) vijand die ondermijnt, en op zijn beurt weer moet worden ondermijnd, vinden we ook terug in de wijze waarop het begrip de Nederlandse veiligheidswereld binnensijpelde. Voor een beter begrip hiervan keren we terug naar 2005, toen de politie het visiedocument Politie in Ontwikkeling (RHC, 2005) publiceerde. Het rapport schetst een beeld van een internationaal steeds verder vervlochten samenleving die door haar openheid met nieuwe gevaren te maken krijgt, waar de politie een antwoord op moet hebben. Daartoe definieert de Raad van Hoofdcommissarissen (RHC) vijf thema's waar de politie zich samen met andere partijen op zou moeten richten: 'ongelijkwaardigheid' (het uitsluiten van burgers en het verdiepen van sociale tegenstellingen), 'overlast' (jongeren, verslaafden of verwarden die de openbare orde verstoren), 
'veelvoorkomende criminaliteit' (fietsendiefstal, zakkenrollerij, enz.), high-impact crimes (geweld, moord, doodslag, verkrachting, enz.) en - jawel - 'ondermijning' (van de democratische rechtsstaat).

Drie jaar later, in 2009, volgt in twee drukken Over ondermijning, een eigen uitgave van de politie-eenheid Amsterdam die in maar liefst 198 pagina's (exclusief omslag en bijlagen) uitlegt wat het begrip inhoudt en vooral ook inventarisaties geeft van ondermijningsvormen die moeten worden bestreden - het zijn er heel wat. In 2010 treedt de politie voor het eerst met het begrip 'ondermijning' naar buiten door de publicatie van een artikelenreeks in het Tijdschrift voor de Politie over de vijf veiligheidsthema's die de RHC indertijd had vastgesteld. Deze artikelen zijn door de eenheid Amsterdam vervolgens gebundeld in het boekje Bijdragen aan Veiligheid (2010), dat richtinggevend werd voor de strategische agenda van de politie. We beschouwen om die reden Auke van Dijk en Frank Hoogewoning, adviseurs van de toenmalige Amsterdamse korpschef Bernard Welten (de grote man achter Politie in ontwikkeling), samen met Chiu Man, toen chef Zware Criminaliteit bij hetzelfde korps, als de geestelijke vaders van het begrip 'ondermijning'. De toenemende vermenging tussen boven- en onderwereld maakt volgens hen een andere manier van kijken naar criminaliteit nodig.

Hun werkdefinitie van 'ondermijning' gaat verder dan het gevaar van georganiseerde criminaliteit (c.q. de vermenging tussen boven- en onderwereld). Hoogewoning et al. (2010: 7-8) omschrijven het begrip als 'het verzwakken of misbruiken van de structuur van onze maatschappij, leidend tot een aantasting van haar fundamenten en/of van de legitimiteit van het stelsel dat haar beschermt'. Volgens hen gaat het bij 'de structuur van de maatschappij' niet louter om de democratische rechtsstaat, maar om haar politieke, financieel-economische, sociaal-culturele, technologische, ecologische en demografische fundamenten. Hierbinnen zijn weer sleuteldomeinen aan te wijzen - personen, groepen, plaatsen, organisaties en branches - die vatbaar zijn voor ondermijning en die bescherming behoeven van politie en justitie, het bestuur, de belastingdienst, scholen, zorginstellingen en wat dies meer zij. De samenleving wordt gemobiliseerd om, zo gezegd, een 'stille oorlog' te voeren.

Hoewel de RHC begon met zorgen over de ondermijnende werking van grensoverschrijdende zware criminaliteit, verschijnen in de bonte inventarisatie ook andere problematische fenomenen. De lijst in Bijdragen aan Veiligheid (2010) bevat naast 'klassieke' vormen van georganiseerde criminaliteit (fraude, witwassen, illegale handel in mensen, goederen en drugs, enz.), ook zaken als religieus extremisme, radicale dierenactivisten, politiek en etnisch extremistische bewegingen, eigenrichting en andere vormen van geweld. In een later artikel vatten Van Dijk en Hoogewoning ondermijning kortweg samen als 'bedreigingen van de integriteit van het systeem' (2014: 9); zij stellen vast dat specifiek bij dit thema 'van succesvolle agendasetting kan worden gesproken' (p. 10). De strategische politieverkenning uit 2005 heeft in circa tien jaar tijd een geheel nieuwe veiligheidsstrategie gebaard, maar daarvoor was eerst nog een populariseringsslag noodzakelijk. 


\section{De grote doorbraak}

Het begrip ondermijning krijgt pas echt vleugels bij de publicatie van het boek van Pieter Tops en Jan Tromp (2017). Tops is hoogleraar Bestuurskunde aan de Tilburg University (en voormalig lid van de Raad van Bestuur van de Politieacademie). Tromp is journalist en oud adjunct-hoofdredacteur van de Volkrant. In een aantrekkelijke stijl schetsen ze de opkomst van de drugsindustrie, de Brabantse context daarvan en vooral de culturele tradities waarbinnen deze kan wortelen. Het boek wordt uitgegeven bij een algemene uitgeverij en is een relatieve bestseller. Het begrip begint na deze publicatie aan een gestage opmars in de publieke opinie en krijgt ook politiek momentum. Figuur 1 is een weergave van de trend in het gebruik van het begrip ondermijning via Google Trends. ${ }^{7}$

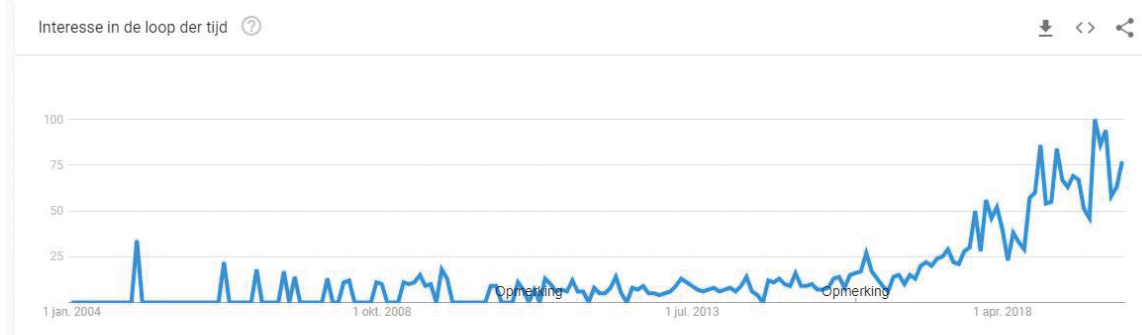

\section{Figuur 1 Google Trends, zoekwoord Ondermijning}

Er zullen diverse publicaties volgen met Tops (2016-2019) als hoofdauteur. Typerend is de publicatie De achterkant van Amsterdam (2019), die als expliciete doelstelling heeft 'de drugsgerelateerde criminaliteit' op de agenda te zetten. Ondanks de nuanceringen en voorbehouden van de auteurs krijgt het rapport veel kritiek. Met name Bart de Koning van het kritische journalistencollectief Follow the money maakt gehakt van het rapport. De Koning (2018) spreekt eerder al van 'paniekzaaierij' en ziet in 'ondermijning' een nieuw wapen van machthebbers om er van alles door te drukken: meer geld voor misdaadbestrijding, een war on drugs en toch maar liever geen gekozen burgemeester (want dat zou een crimineel kunnen zijn).

Het lijkt een wat simplistische manier om de speech act 'ondermijning' verdacht te maken. De Koning wijst op het risico van verhevigd politiek misbruik van 'ondermijning', vanwege het onzichtbare karakter. Maar het is dan wel weer wat tegenstrijdig dat hij een groot tekort signaleert in de opsporing. Juist via opsporingsonderzoeken ontstaat zicht op wat gaande is (zie bijv. Kruisbergen et al., 2012). Veel van de schattingen van Tops et al. zijn gebaseerd op een extrapolatie van de 'vangsten', zoals de $€ 18,9$ miljard omzet in de synthetische drugs (Tops et al., 2018). Deze schattingen kunnen algauw worden betwist, omdat het uiteindelijk maar om schattingen gaat. Dit leidt tot een onvermijdelijke strijd tussen alarmisten en rela- 
tivisten. De eersten schreeuwen het van de daken, de anderen zien het zo'n vaart niet lopen.

De vangsten zijn echter zo groot en zo frequent, dat relativering niet op zijn plaats lijkt. Zelfs als van de schattingen maar de helft echt hard te maken is, dan blijft de situatie nog verontrustend. Voor de Amsterdamse publicatie van Tops geldt volgens gekwalificeerde inside information inderdaad dat de opdracht aan hem een politieke bedoeling had - in het collegeakkoord werd met geen woord gerept over de drugscriminaliteit. De discussie over mogelijk politiek misbruik achten we echter te sterk aangezet, als we ervan uitgaan dat de fenomenen waarnaar verwezen wordt reëel zijn, dat wil zeggen voldoende realiteitswaarde hebben om het ondermijningsdiscours te onderhouden. We hebben te maken met een speech act met referenties naar realistische problemen. We maken een nadere analyse van de fenomenen waar de term over de afgelopen jaren voor is gebruikt.

\section{Twee ondermijningsdiscoursen}

Vanuit de hiervoor beschreven opkomst van het begrip ondermijning herkennen we in het spreken over ondermijning twee discoursen. In de eerste plaats gaat het over fenomenen die van oudsher op de veiligheidsagenda staan: smokkel (Brabant), fraude, mensenhandel, wapenhandel en natuurlijk drugs. In de jaren negentig werden veel van deze vormen samengenomen onder de noemer georganiseerde misdaad. In de tweede plaats wordt veelvuldig gewezen op problematisch gedrag dat de sociale kwaliteit van de samenleving aantast. Vaak is er een relatie met criminaliteit, maar dit hoeft niet noodzakelijkerwijze het geval te zijn (bijvoorbeeld religieus extremisme). In het eerste geval is nadrukkelijk sprake van economisch gewin, in het tweede geval kunnen meer ideële motieven een rol spelen. We maken een onderscheid tussen het discours van de georganiseerde misdaad en dat van subversief gedrag.

\subsection{Georganiseerde misdaad}

De wereld van criminaliteit en strafrecht (en dus ook criminologie) is sterk gericht geweest op commune criminaliteit, meer in het bijzonder wat sinds de eeuwwisseling high impact crime is gaan heten. Daarbij gaat het om delicten die burgers direct en serieus treffen, zoals inbraak, overvallen en geweldsdelicten. In de jaren negentig is er een tweede veiligheidslijn ontstaan rond het begrip georganiseerde misdaad. In een overzichtsartikel van Huisman en Kleemans (2017) wordt de opkomst van het discours rond georganiseerde misdaad beschreven vanuit de vraag wat het begrip ondermijning daaraan eigenlijk toevoegt.

Ook in de jaren negentig is zwaar gebakkeleid over de vraag wat georganiseerde misdaad nu eigenlijk was. De term kwam overgewaaid uit de Verenigde Staten in relatie tot de maffia. Het pleit werd min of meer beslecht door de Parlementaire Enquêtecommissie Opsporingsmethoden (1996):

'Er is sprake van georganiseerde criminaliteit indien groepen die primair gericht zijn op illegaal gewin systematisch misdaden plegen met ernstige 
gevolgen voor de samenleving, en in staat zijn deze misdaden op betrekkelijk effectieve wijze af te schermen, in het bijzonder door de bereidheid te tonen fysiek geweld te gebruiken of personen door middel van corruptie uit te schakelen.'

Deze definitie werd nadien gangbaar en kreeg behoorlijk veel implicaties voor het beleid. Zo werden de Wet bijzondere opsporingsbevoegdheden (Wet BOB) en de Wet bevordering integriteitsbeoordelingen door het openbaar bestuur (Wet Bibob) ingevoerd, en kondigde het ministerie van Justitie en Veiligheid een kabinetsbreed programma 'Versterking Aanpak Georganiseerde Misdaad' af (Kamerstukken II 2007/08). Het vormde het begin van een reeks van maatregelen, waaronder de oprichting van RIEC's en van het LIEC. De gelegenheidsstructuren voor georganiseerde misdaad dienden ook bestuurlijk te worden aangepakt. In 2009, 2012 en 2016 is onderzoek gedaan naar de invulling van deze bestuurlijke aanpak (Smit \& Struiksma, 2017). Het bewustzijn van de problemen bij gemeenten blijkt te zijn toegenomen, van $84 \%$ in 2012 naar 97\% in 2016. De meeste gemeenten zien het belang van een aanpak van georganiseerde criminaliteit (met name grootschalige hennepteelt). Een vergelijkbaar positief beeld wordt geschetst van de organisatie van het RIEC-LIEC-bestel (Smit \& Struiksma, 2017).

Huisman en Kleemans (2017) stellen dus niet voor niets de vraag waarom nieuwe begrippen en nieuwe instrumenten nodig zouden zijn: 'Het gaat immers goed.' In hun antwoord wijzen ze er wel op dat de term 'georganiseerde misdaad' misschien meer belooft dan kan worden waargemaakt. Zo georganiseerd blijkt die vaak niet te zijn, terwijl andere vormen van criminaliteit, bijvoorbeeld van bedrijven zelf, veel grotere schadeposten voor de samenleving met zich meebrengen. Ook 'georganiseerde misdaad' blijft met andere woorden een enigszins arbitraire term, waarbij de notie van 'illegaal gewin' centraal staat - economische motieven staan voorop. Vanwege het enigszins beperkte karakter van de term georganiseerde misdaad is klaarblijkelijk behoefte aan een nieuwe term: 'ondermijning'.

Het is een alternatief waarmee het perspectief en de aanpak kunnen worden verbreed, waardoor ook de doorwerking in de reguliere samenleving kan worden gethematiseerd. 'Ondermijning is een gevolg', aldus een publicatie van de Nederlandse School voor Openbaar Bestuur (NSOB - Van der Steen et al., 2016: 4):

'Georganiseerde ondermijnende criminaliteit duidt op georganiseerde criminaliteit, die de legale en beoogde werking van het samenlevingssysteem aantast. Georganiseerde criminaliteit is dan de oorzaak, het ondermijnende effect op de samenleving is één van de gevolgen - en niet per se het door de criminelen beoogde effect.'

In het eerste ondermijningsdiscours gaat het dus nadrukkelijk om georganiseerde misdaad waarbij het economische motief vooropstaat en de maatschappelijke effecten centraal staan. Het versterkt een brede maatschappelijke aanpak, die al decennia op het verlanglijstje van beleidsmakers staat en in verschillende gedaanten steeds weer oppiept (van criminaliteitspreventie tot integrale veiligheid). 
Maar de urgentie wordt groter vanwege de enorme economische belangen en de ongrijpbaarheid van de doorwerking in de legale sectoren.

\subsection{Subversief gedrag}

In de ontwikkeling van het begrip ondermijning zit nog een tweede discours, dat niet te maken heeft met 'illegaal gewin'. Hier spelen meer ideële motieven een rol. Een voorbeeld hiervan is de Kamerbrief over salafisme:

'Ondermijning is te definiëren als stelselmatige, doelbewuste en in vele gevallen heimelijke activiteiten die door de nagestreefde doelen, de gebruikte middelen of ressorterende effecten de democratische rechtstaat, de bijbehorende instituties en onderlinge samenhang tussen burgers verzwakken, destabiliseren, ondergraven of saboteren. Te denken valt daarbij aan het stelselmatig en dwingend afwijzen of belemmeren van democratische processen (zoals raadsvergaderingen en verkiezingen) en het gezag van democratisch-rechtstatelijke instituties (zoals de rechterlijke macht en overheid). Dergelijke problematische gedragingen zijn, ook wanneer zij niet vallen binnen het strafrechtelijke kader, onacceptabel.' (Minister van SZW, 2019b)

Deze omschrijving verwijst naar gedragingen die meer als onwettelijk of als onwenselijk kunnen worden beschouwd, hoewel ze uiteindelijk ook kunnen leiden tot strafbaar gedrag. In eigen onderzoek voor het ministerie van Binnenlandse Zaken en Koninkrijksrelaties (BZK) naar dergelijke niet-economische vormen van ondermijning kwamen we allerlei gedragingen tegen die op heel verschillende gronden door gemeenten als problematisch worden gezien: straatjeugd, geïsoleerde gemeenschappen, excessief middelengebruik en dergelijke. In een overkoepelende analyse van onderzoek in vijf Nederlandse gemeenten onderscheiden we naast economische motieven ook 'politiek onbehagen' en 'isolement' als vormen van ondermijnend gedrag (Boutellier et al., 2019). Bij het eerste kan worden gedacht aan ongeorganiseerd verzet (bijv. tegen een zwartepietdemonstratie of de vestiging van een $\mathrm{AZC}$ ). Bij het tweede aan problematisch gedrag van bijvoorbeeld salafistische of streng gereformeerde groepen (beide vertegenwoordigd in het onderzoek).

Er kan sprake zijn van onverdraagzaamheid ten aanzien van andersdenkenden of andersgelovigen, of verzet tegen de gelijkheid van man en vrouw (zie ook Analistennetwerk Nationale Veiligheid, 2016). Er wordt soms opgeroepen tot verzet tegen de overheid of tot zo min mogelijk contact met autoriteiten of andersdenkenden. Daarbij wordt de hang naar het volgen van de eigen religieuze wet- en regelgeving (en haar normen) belangrijker dan die van de Nederlandse democratische rechtsorde. De NCTV (2016) spreekt zijn zorgen uit dat religieuze opvattingen bij individuen ervoor kunnen zorgen dat zij vanuit ideologisch motief bereid zijn in ernstige mate de wet te overtreden of activiteiten te verrichten die de democratische rechtsorde ondermijnen. Zulke gemeenschappen worden als problematisch gezien zodra het (lokaal) bestuur (door hen) wordt belemmerd in het uitoefenen van gezag en handhaving. Dit geldt ook voor groepen die worden gedreven door een vorm van collectieve eigenrichting (Kronjee, 2006; Balogh et 
al., 2009), zoals Outlaw Motorcycle Gangs, woonwagenkampen, gesloten familiestructuren of bepaalde buurten of straten (Jansen, 2017).

Naast ideële of tribale vormen van subversief gedrag, worden ook relatief ongerichte vormen van onvrede en onbehagen als ondermijnend gezien. Het zichtbaar uiten van wat burgers dwarszit, gebeurt niet vanuit een crimineel motief, maar vanuit een opeenhoping van emoties waar ze zelf geen uitweg voor zien (zie bijv. De Lange \& Zuure, 2017). Burgers zetten zich in om de verstoring van hun cultuur en sociale omgeving tegen te gaan. Er is sprake van het agenderen van zorgen (Steur et al., 2017), waarbij vaak niet zozeer de overheid maar eerder 'de elite' of andere bevolkingsgroepen als tegenstander worden gezien. Dit kan leiden tot geweld of een structurele aantasting van de sociale stabiliteit, bijvoorbeeld bij protest tegen de opvang van asielzoekers (Meulenbelt, 2017). Deze relatief ongecoördineerde vormen van verzet kunnen onwettelijk zijn of tot strafbaar gedrag leiden en worden meegenomen in het tweede 'ondermijningsdiscours'.

\section{De toespitsing op de drugsindustrie}

Best wel bizar dus, de speech act 'ondermijning'; het gaat overal en nergens over, maar heeft een mobiliserende politieke impact. Gemeenschappelijk aan de twee onderscheiden discoursen lijkt in ieder geval dat sprake is van relatief onzichtbare vormen van illegaliteit die sterk verweven zijn met de reguliere wereld (Boutellier, 2019). We zetten de analyse nog even voort en constateren dat in het beleid de drugsindustrie (productie, handel en consumptie) geleidelijk de overhand krijgt. Dit blijkt bijvoorbeeld uit de keuzes van het Strategisch Beraad Ondermijning (2019), die de middelen volledig inzet op de aanpak daarvan. De drugsindustrie kon in Nederland groeien op het succes van het gedoogbeleid en een goede infrastructuur. We gaan hier wat dieper op in, omdat het duidelijk maakt binnen wat voor een context het spreken over ondermijnende criminaliteit vorm krijgt.

\subsection{Morele ambiguïteit}

Het Nederlandse drugsbeleid kenmerkt zich vanaf de jaren zeventig door het zogenoemde gedogen. Dit woord staat voor een benadering waarin onwettige en/ of onwenselijke praktijken tegelijkertijd toch geregeld worden (zie bijv. Van der Noort \& Wiche, 2006). Het gezondheidsperspectief is daarin (met succes) doorslaggevend geweest. Rond marihuanagebruik heeft zich een wereld van coffeeshops ontwikkeld die aan de voordeur openstaat, maar aan de achterdeur op slot zit. Gebruiken mag, productie en handel niet. Iets vergelijkbaars geldt voor synthetische drugs die volgens de Opiumwet zijn verboden, maar op festivals en dancefeesten worden toegelaten (veelal gecontroleerd door de GGD). Het gaat gepaard met een ten opzichte van andere landen mild strafklimaat voor drugsdelicten.

Over de politieke wenselijkheid van dit drugsbeleid valt zonder meer te twisten. We constateren in ieder geval dat er tegenstrijdigheden zijn tussen de wetgeving, de naleving daarvan en de handhaving. Het gedoogbeleid heeft geleid tot terughoudend beleid in de aanpak, weinig prioritering in de handhaving en een laco- 
nieke houding bij publieke en maatschappelijke organisaties. Zoals in de Toekomstagenda Ondermijning (Minister van Veiligheid en Justitie, 2017) wordt gesteld, manifesteert ondermijnende criminaliteit zich bij uitstek waar niet of onvoldoende wordt opgetreden. Gebrek aan handhaving in parallelle gelegenheidsstructuren, zoals bepaalde achterstandswijken, verwaarloosde bedrijventerreinen, woonwagencentra of recreatieparken, versterkt de voedingsbodem. Nederland liep voorop in zijn tolerante gedoogbeleid, maar lijkt als een tovenaarsleerling krachten te hebben ontketend die het niet meer in de hand kan houden.

\subsection{Een criminogene fysieke infrastructuur}

Nederland kent een materiële gelegenheidsstructuur die internationaal zijn weerga niet lijkt te kennen. Deze is goed voor elk soort onderneming, en dat geldt zeker ook voor de drugsindustrie. Er komen op zijn minst vijf opvallende kenmerken in de Nederlandse context bij elkaar:

- de aanwezigheid van grote (lucht)havens (plus de toegangsroute via de haven van Antwerpen) en talloze kleinere havens met uitstekende overslagvoorzieningen;

- open grenzen met intensief personen- en goederenvervoer;

- goede digitale voorzieningen, een gunstig ondernemersklimaat en een fraudegevoelige financiële dienstverlening;

- een sterk ontwikkelde agrarische sector, inclusief veel leegstand van grote schuren en loodsen;

- een transnationale bevolkingssamenstelling die contacten met het buitenland faciliteert.

De drugsindustrie kan zich dus nestelen in een relatief open netwerksamenleving met navenant toegankelijke systemen. Door de enorme opbrengsten raakt de drugsindustrie verbonden met reguliere instellingen, specifieke locaties en alledaagse omstandigheden in de (achterstands)wijken, op de bedrijfsterreinen en in de vakantieparken. Nederland heeft een aantal aantrekkelijke criminogene condities gecreëerd voor ondernemende personen die het zo nauw niet nemen met wet- en regelgeving en het algemeen belang van de Nederlandse samenleving. Het weerspiegelt een samenleving die de greep op haar 'systeem' lijkt te verliezen. Het vormt een ideale mentale context voor de semantische zegetocht van het begrip ondermijning - de speech act ondermijning heeft zo zijn redenen.

\section{Nadere analyse}

Het begrip ondermijning is vanuit een zeer breed perspectief versmald tot de aanpak van de drugswereld, en meer in het bijzonder de effecten daarvan. Daarin is nog steeds sprake van een breed palet aan illegaliteit. Vanaf de ene kant kan worden gewezen op regelrecht crimineel gedrag dat vaak samenhangt met drugscriminaliteit (productie, afvaldump, handel en consumptie). Het gaat daarbij vaak om fluïde criminele groepen (netwerken), die uit zijn op economisch gewin. Er gaat veel geld in om, waarmee vastgoed wordt gekocht, jongeren worden geron- 
seld en functionarissen worden omgekocht. En af en toe valt er een slachtoffer bij de (onbedoelde) liquidatie van een concurrent. De moord op advocaat Derk Wiersum is het voorlopige dieptepunt in de criminele strijd.

Vanaf de andere kant ontwikkelt zich omstreden en onwenselijk gedrag op basis van reguliere activiteiten of ondernemingen. Denk aan autoverhuurbedrijven, makelaars, boeren met leegstaande loodsen, recreatieparkhouders en wat dies meer zij. Vaak ontbreekt de morele remming of de handhaving en het toezicht om te voorkomen dat er een proces van afglijden ontstaat. Er kan ook sprake zijn van afkeer van overheidsgezag of van verloedering of puur berekenend gedrag. Er ontstaat zo een voedingsbodem die ondersteunend is aan criminele (drugs)handel. Van twee kanten ontstaat een veld van (illegale) activiteiten waar het lokale bestuur zich verantwoordelijk voor voelt, en waarvoor het onder de noemer 'ondermijning' nog zoeken is naar de juiste strategieën.

Dit brede veld van illegaliteit ontstaat in een context die we kunnen typeren als 'complex zonder richting' (Boutellier, 2011). Veel problemen zijn vertakt via netwerkstructuren en vragen om een navenante aanpak. Ondermijning verwijst naar de illegale warboel die kan groeien binnen legale complexiteit. Zij heeft te maken met open netwerk- en gelegenheidsstructuren die onoverzichtelijk zijn en een sfeer van dreiging oproepen. In die zin appelleert de speech act ondermijning aan het soort onbehagen dat eerder in verband werd gebracht met de securitisering van de samenleving: cultureel onbehagen en een onbestemd verlangen naar zekerheid (Spithoven, 2017). Ondermijning verwijst naar de gemoedstoestand van een complexe samenleving die constant op haar hoede is. Daarom kreeg het een sterk mobiliserende werking - zoveel is duidelijk.

Deze ambigue situatie kan leiden tot politieke overstressing van het begrip ondermijning. Juist omdat de aanpak vraagt om onorthodoxe maatregelen (Boutellier et al., 2017) is het van belang dat risico te onderkennen en deze ook in de sociale sfeer te treffen. We hebben in nog niet gerapporteerd onderzoek bovendien gezien dat de speech act 'ondermijning' weliswaar mobiliserend werkt, maar in de operatie verlamt, omdat onduidelijk is waarop moet worden ingezet. Het lijkt wenselijk beide discoursen te onderscheiden, waarbij het voor de hand ligt in het eerste discours te spreken van 'de drugsindustrie' en alle illegale activiteiten daaromheen concreet te benoemen. Daarnaast heeft Nederland te maken met ontwikkelingen die onwettelijk en onwenselijk zijn vanuit een oogpunt van maatschappelijke continuïteit. In feite is het begrip ondermijning op dit tweede discours veel beter van toepassing, maar we zijn voorbij aan het mobiliserende effect ervan: het raakt op. Het einde van de speech act ondermijning komt in zicht, maar de problemen zullen nog wel even voortwoekeren.

\section{Literatuur}

Analistennetwerk Nationale Veiligheid (2016) Nationaal veiligheidsprofiel 2016: een AllHazard overzicht van potentiële rampen en dreigingen die onze samenleving kunnen ontwrichten. Den Haag: Rijksinstituut voor Volksgezondheid en Milieu. 
Balogh, L., M. Siesling, M. Jacobs \& H. Moors (2009) Eigenheid of eigenzinnigheid. Analyse van cultuur-en geloofsgerelateerde denkbeelden en gedragsuitingen in de gemeente Ede. Ede: IVA.

Berger, M., M. Kahmann, S. El Baroudi \& A. Hamdi (2018) Salafisme in Nederland belicht; Vijftien jaar salafisme onderzoek in Nederland. Utrecht: Verwey-Jonker Instituut.

BNR (2018) Grapperhaus wil vrijheid van meningsuiting wel/niet inperken. Geraadpleegd op 5 oktober 2018: www.bnr.nl/nieuws/politiek/10341790/grapperhaus-wil-vrijheidvan-meningsuiting-wel-niet-inperken.

Boutellier, H. (2002) De veiligheidsutopie. Hedendaags onbehagen en verlangen rond misdaad en straf. Den Haag: Boom Juridische uitgevers.

Boutellier, H. (2011) De improvisatiemaatschappij. Over de sociale ordening van een onbegrensde wereld. Den Haag: Boom Lemma.

Boutellier, H. (2018) De ondermijnisering van veiligheid. Geraadpleegd op 5 oktober 2018: www.gemeente.nu/blog/de-ondermijnisering-van-veiligheid.

Boutellier, H. (2019) Het seculiere experiment. Westerse waarden in radicale tijden. Den Haag: Boom Uitgevers.

Boutellier, H., J. Broekhuizen, M. van Kapel en F. Hermens (2016) De Taskforce Brabant Zeeland wetenschappelijk tegen het licht gehouden; Strategisch advies. Utrecht: VerweyJonker Instituut.

Boutellier, H., Y. Eski, M. Boelens \& J. Broekhuizen (2019) Zicht en Greep: Overkoepelende analyse BZK-project Lokale ondermijning en weerbaar bestuur. Utrecht: Verwey-Jonker Instituut.

Brouwer, J. (2018) 'Ondermijning' is een loos begrip. Geraadpleegd op 5 oktober 2018: www.nrc.nl/nieuws/2018/10/01/ondermijning-is-loos-begrip-a2040596.

Burawoy, M. (2005) For public sociology. American sociological review, 70(1), 4-28.

Buzan, B., O. Wæver \& J. de Wilde (1998) Security: a new framework for analysis. Londen: Lynne Rienner Publishers.

Dijk, A.J. van \& F. Hoogewoning (2015) Vergezichten naderbij: maatschappelijke ontwikkelingen en hun praktische betekenis voor de politie. Cahiers Politiestudies, 5(33): 83-102.

Eysink Smeets, M. (2018) Wie nog weet wat ondermijning precies is, mag het zeggen. Geraadpleegd op 5 oktober 2018: www.nrc.nl/nieuws/2018/02/15/wie-nog-weet-watondermijning-precies-is-mag-het-zeggen-a1592372.

Gemeente Amsterdam (2018) Vergadering Expertmeeting commissie AZ: Ondermijnende Criminaliteit 18-09-2018. Geraadpleegd op 5 oktober 2018: https:// amsterdam.raadsinformatie.nl/vergadering/551609/Expertmeeting\%20commissie \%20AZ\%3A\%20Ondermijnende\%20Criminaliteit\%2018-09-2018.

Hoogenboom, B. (2018) Ondermijning is heus niet alleen iets voor drugscriminelen. Geraadpleegd op 5 oktober 2018: www.nrc.nl/nieuws/2018/07/26/ondermijning-isheus-niet-alleen-iets-voor-drugscriminelen-a1611259.

Hoogewoning, F. \& B. Welten (2010) Bijdragen aan veiligheid: strategische verkenningen. Tijdschrift voor de Politie, 72(2), 5-9.

Hoogewoning, F., A. van Dijk \& W. Man (2010) Ondermijning en veiligheid. Tijdschrift voor de Politie, 72(5), 6-10.

Huisman, W. \& E.R. Kleemans (2017) Organisatiecriminaliteit, georganiseerde criminaliteit en ondermijning. In: R. Staring, R. van Swaaningen \& K. van Wingerde (red.), Over de muren van stilzwijgen (p. 535-548). Den Haag: Boom Uitgevers.

Jansen, A. (2017) Toekomstagenda als actieagenda. Ondermijning. Geraadpleegd op [datum]: www.regioburgemeesters.nl/publish/pages/662/ toekomstagenda_ondermijning.pdf. 
Kamerstukken II 2007/08, 29911, nr. 10 (Kamerbrief van de minister van Justitie over bestrijding van georganiseerde criminaliteit).

Koning, B. de (2018) Ondermijning ondergraaft vooral ons gezonde verstand. Website Follow the Money, 8 december 2018.

Kronjee, G. (2006) De religieuze transformatie en de sociale cohesie. In: W.B.H.J. van de Donk, A.P. Jonkers, G.J. Kronjee en R.J.J.M. Plum (red), Geloven in het publieke domein: Verkenningen van een dubbele transformatie (p. 89-138). Amsterdam: Amsterdam University Press.

Kruisbergen, E.W., H.G. van de Bunt, E.R. Kleemans (red.) (2012) Georganiseerde criminaliteit in Nederland; Vierde rapportage op basis van de Monitor Georganiseerde Criminaliteit. Den Haag: Boom Lemma.

Lange, S. de \& J. Zuure (2017) Over een onbevreesd openbaar bestuur dat voorbereid is op verontwaardigde burgers. In: S. de Lange \& J. Zuure (red.), \#WOEST. De kracht van verontwaardiging. Amsterdam: AUP/Raad voor het Openbaar Bestuur.

Meulenbelt, S. (2017) Migratiestroom: brandstof voor ordeverstoring, ondermijning en terrorisme?. Magazine Nationale Veiligheid en Crisisbeheersing, 15(1): 20-22.

Minister van SZW (2019a) Integrale aanpak Problematisch gedrag en ongewenste buitenlandse financiering van maatschappelijke en religieuze instellingen. Kamerbrief 11 februari 2019.

Minister van SZW (2019b), Kamerbrief Integrale aanpak Problematisch gedrag en ongewenste buitenlandse financiering van maatschappelijke en religieuze instellingen. Kamerbrief 2019-0000013831.

Minister van Veiligheid en Justitie (2017) Toekomstagenda Ondermijning. Tweede Kamer der Staten-Generaal 2016-2017, 29911, nr. 167.

NCTV (2016) Nationaal Contraterrorismestrategie 2016-2020. Den Haag: Nationaal Coördinator Terrorismebestrijding en Veiligheid.

Noort, W.J. van \& R.T.P. Wiche (2006) Nederland als voorbeeldige natie. Hilversum: Uitgeverij Verloren.

NOS (2018) Grapperhaus wil met Kamer strafrecht veranderen om 'walgelijke' woorden imam. Geraadpleegd op 5 oktober 2018: http://nos.nl/artikel/2224587-grapperhauswil-met-kamer-strafrecht-veranderen-om-walgelijke-woorden-imam.html.

Parlementaire Enquêtecommissie Opsporingsmethoden (1996) Inzake Opsporing; enquête opsporingsmethoden, eindrapport, Kamerstukken II, 1995/96, 24072, nr. 16, p. 24.

Politie Amsterdam-Amstelland (2009) Over ondermijning. Een verkenning naar het fenomeen, de aanpak en mogelijke verbeteringen. Geraadpleegd op 13 januari 2020: https:// respubca.home.xs4all.nl/pdf/Over\%200ndermijning_2edruk_bew.\%20Amsterdam \%20Chiu\%20Man.\%20pdf.pdf.

Powelson, M. (2003) US support for anti-Soviet and anti-Russian guerrilla movements and the undermining of democracy. Demokratizatsiya-Washington, 11(2): 297-304.

Rijksoverheid (2018) Toespraak van minister Grapperhaus bij de conferentie 'Versnelling aanpak ondermijning'. Geraadpleegd op 5 oktober 2018: www.rijksoverheid.nl/ documenten/toespraken/2018/06/21/toespraak-van-minister-grapperhaus-bij-deconferentie-versnelling-aanpak-ondermijning.

Simon, J. (2007) Governing through crime: How the war on crime transformed American democracy and created a culture of fear. New York: Oxford University Press.

Smit, J., N. Struiksma \& B. Schudde (2017) Bestuurlijke aanpak georganiseerde criminaliteit. Onderzoek stand van zaken 2016. Arena Consulting en Pro Facto i.o.v. WODC.

Spithoven, R. (2017) Keeping trouble at a safe distance: Unravelling the significance of the fear of crime. Boom Den Haag: Eleven.

Steen, M. van der, J. Schram, N. Chin-A-Fat \& J. Scherpenisse (2016) Ondermijning ondermijnd. Den Haag: NSOB. 
Steur, B., T. Zandstra \& E. van Doorne (2017) Omgaan met het onbehagen. Binnenlands Bestuur, 16, 24-26.

Strategisch Beraad Ondermijning (2019) Brief advies synthetische drugs SBO. www.rijksoverheid.nl/documenten/rapporten/2019/02/15/tk-bijlage-strategischeberaad-ondermijning.

Theoharis, A. (2003) Dissent and American Culture: the Undermining of an Anti-Communist Consensus, 1950-1976. In: P.M. Madrazo (red.), Visiones contemporáneas de la cultura y la literatura norteamericana en los sesenta (p. 107-118). Sevilla: Universidad de Sevilla.

Tops, P. (2018) Een ongetemde buurt. Achterstand, ondernemingszin en criminaliteit in een volksbuurt. Amsterdam: Balans.

Tops, P. \& H. Schilders (2016) Naar een meervoudige aanpak van ondermijning. Tijdschrift voor de Politie, 78(7), 12-15.

Tops, P. \& J. Tromp (2019) De achterkant van Amsterdam; een verkenning van drugsgerelateerde criminaliteit. Amsterdam: Gemeente Amsterdam.

Tops, P., J. van Valkenhoef et al. (2018) Nederland en synthetische drugs: een ongemakkelijke waarheid. Den Haag: Boom Criminologie.

Tops, P., J. van Valkenhoef, E. van der Torre \& L. van Spijk (2018) Waar een klein land groot in kan zijn; Nederland en synthetische drugs in de afgelopen 50 jaar. Den Haag: Boom Criminologie.

Torre, E. van der \& P. Tops (2018) Gebiedsgebonden politie: hervorming is broodnodig. Apeldoorn: Politieacademie.

Tromp, J. \& P. Tops (2017) De achterkant van Nederland: Hoe onder- en bovenwereld verstrengeld raken. Amsterdam: Balans.

Welten, B.J.A.M. (2005) Politie in ontwikkeling. Visie op de politiefunctie. Den Haag: NPI.

Zouridis, S., P.W Tops \& R. Peeters (2013) Bestrijding van criminele ondermijning in NoordBrabant: De Taskforce B5 als katalysator van samenwerking. Tilburg: Tilburgse School voor Politiek en Bestuur, Tilburg University. 